\title{
IMPACTS OF LONG-TERM FERTILIZATION ON BACTERIAL COMMUNITY STRUCTURE, SOIL MICROBIAL BIOMASS, AND GRAIN YIELDS IN RED PADDY SOIL IN CHINA
}

\author{
QIAO, Y. J. ${ }^{1}-$ LIU, Q. ${ }^{1}-$ GAO, Z. Q. $.^{1 *}-$ GE, J. Y. ${ }^{2}-$ FENG X. M. ${ }^{2}-$ XUE, J. F. ${ }^{1}-$ SUn, M. ${ }^{1}$ \\ ${ }^{1}$ College of Agronomy, Shanxi Agriculture University, Taigu 030801, China \\ ${ }^{2}$ College of Agronomy, China Agriculture University, Beijing 100193, China \\ *Corresponding author \\ e-mail: gaozhiqiang1964@126.com; phone:+86-0354-628-7226
}

(Received $16^{\text {th }}$ Dec 2018; accepted $8^{\text {th }}$ Feb 2019)

\begin{abstract}
Bacteria play essential roles in soil ecosystems. This study aims to investigate rice rhizosphere bacterial communities, soil nutrition, and grain yield affected by long-term (30 years) fertilization practices. Four fertilizations were applied to experimental red paddy soils: no fertilizer (NF), chemical fertilizer (CF), harvested residue returned to soil (HRR), and $60 \%$ organic manure plus chemical fertilizer (OCF). Bacterial communities were then assessed by means of denaturing gradient gel electrophoresis (DGGE) targeting 16S rRNA genes. Results showed that the bacterial community structure of OCF was similar to HRR, which was the most diverse and stable compared to the other treatments. Moreover, CF's effects were similar to NF, which was markedly less diverse. Eight bacterial phyla were identified by sequence analysis of the DGGE bands from rhizosphere inhabitants in the red paddy soils. In addition, soil microbial biomass $\mathrm{C}$ and $\mathrm{N}$ were significantly higher in HRR and OCF than in CF and NF. Furthermore, double rice grain yield and dry matter in OCF plots were significantly highest $(P<0.05)$. Long-term treatment of organic matter containing fertilizers promoted rhizospheric bacterial diversity and soil quality. The combination of inorganic and organic fertilizers (OCF) improved grain yields more than solely inorganic (CF) or organic (HRR) fertilizers.
\end{abstract}

Keywords: bacterial community, rhizosphere soil, denaturing gradient gel electrophoresis (DGGE), long-term fertilization, double rice, dry matter

\section{Introduction}

Soil quality is an important indicator of ecosystem health and soil sustainability. It can be assessed by physical, chemical, and biological approaches (Karlen et al., 2003). Bacterial communities are one of the most sensitive biological indicators of soil quality (Kennedy, 1999). Appropriate community structure, abundant diversity, and high bacterial activity are all significant factors in maintaining the sustainability and productivity of agro-ecosystems. Research on the relationship between bacterial communities and soil quality has gained traction in the past decade, primarily due to environmental issues that arise from soil degradation in various farming systems.

Rice (Oryza sativa L.) paddy fields can be defined as an anthropogenic soil type formed under long-term water management with seasonal submergence. In China, red soil is one of the most typical arable soils in the subtropical regions covering approximately 1.13 million $\mathrm{km}^{2}$, accounting for $11.8 \%$ of its land surface, and producing $80 \%$ of the rice for $22.5 \%$ of the population (Zhang, 2006). However, due to rapid economic and social development, red soils are subject to degradation, characterized by low organic carbon content and low crop productivity (Wang, 1998). In order to maintain the productivity of red soils, different chemical and organic fertilizers have been applied. Studies have shown that crop yields as well as soil physicochemical and biochemical characteristics change 
with different fertilization treatments (Fierer et al., 2012; Mooshammer et al., 2014; Williams et al., 2013).

Previous studies on the effects of long-term fertilization on microbial community structure and soil quality are however limited. Yet, the few existing studies have revealed that long-term fertilization affects crop yields (Chen et al., 2017), the structure of microbial populations (Gao et al., 2015), the diversity of arbuscular mycorrhizal fungi (Wu et al., 2011), and soil organic matter fractions (Gong et al., 2009). Thus, long-term field trials are important in assessing management, particularly in terms of crop production, soil fertility, and environmental impact (Dobermann et al., 2000).

Therefore, this study has focused on how bacterial community structure, soil quality, and crop yield are affected in double rice-cropping systems by long-term application of inorganic fertilizer (CF), rice straw (HRR), and organic manure plus chemical fertilizer (OCF). This has been done as to provide further information about the complex interactions among soil microbes, soils, and plants. Our highest priority aim has been to evaluate rice rhizospheric bacterial communities in red soils with various fertilization types at different growth stages. Towards this end, denaturing gradient gel electrophoresis (DGGE) and following bands' sequencing were employed to phylogenetically determine the dominant bacterial members.

In sum, we have described the bacterial communities in rice rhizosphere soils that had been subjected to different fertilization regimes since 1986. In addition, the quality of soil and the yield of plants from soils with various treatments were also assessed by evaluating soil biomass, rice grain yields, and dry matter. Our results provide more insight into the effects of fertilization on soil bacteria populations. This in turn helps farmers select best fertilization practices in order to improve soil quality in southern China.

\section{Materials and methods}

\section{Experimental site}

This study was conducted at the experimental field of the Soil and Fertilizer Institute, Hunan Academy of Agricultural Sciences, Ningxiang County, Hunan Province $\left(110^{\circ} 72^{\prime} \mathrm{E}, 28^{\circ} 52^{\prime} \mathrm{N}\right)$, China. The annual average temperature of this region is $14.7-22^{\circ} \mathrm{C}$, and annual rainfall is $1232 \mathrm{~mm}$. The properties of soil before sampling was characterized and listed as follows: soil $\mathrm{pH}$ of 5.3, soil containing organic carbon $\left(50.7 \mathrm{~g} \mathrm{~kg}^{-1}\right)$, total $\mathrm{N}$ (2.1 $\left.\mathrm{g} \mathrm{kg}^{-1}\right)$, total $\mathrm{P}\left(0.73 \mathrm{~g} \mathrm{~kg}^{-1}\right)$, available $\mathrm{N}\left(135.2 \mathrm{mg} \mathrm{kg}^{-1}\right)$, available $\mathrm{P}\left(29.8 \mathrm{mg} \mathrm{kg}^{-1}\right)$, and available $\mathrm{K}\left(52 \mathrm{mg} \mathrm{kg}^{-1}\right)$.

\section{Experimental design}

The rhizospheric soil samples were collected from control and long-term fertilizer treatment soils during April-October 2016. The four treatments were no fertilizer (Gu et al.) as a control, chemical fertilizer (CF), harvested rice straws returned to the soil (HRR), and organic manure plus chemical fertilizer $(\mathrm{OCF})$. The chemical fertilizer was composed of $\mathrm{P}_{2} \mathrm{O}_{5}\left(75 \mathrm{~kg} \mathrm{hm}^{2-1}\right), \mathrm{K}_{2} \mathrm{O}\left(100 \mathrm{~kg} \mathrm{hm}^{2-1}\right)$, and urea $\left(200 \mathrm{~kg} \mathrm{hm}^{2-1}\right)$. Rice straws with equal amount of nitrogen as chemical fertilizer were returned to the field in HRR. The manure of OCF was post-fermented and purchased from a pig farm. The average composition of the pig manure was 588 of organic matter $\left(\mathrm{g} \mathrm{kg}^{-1}\right), 26.7$ of N $\left(\mathrm{g} \mathrm{kg}^{-1}\right), 17.6$ of $\mathrm{P}\left(\mathrm{g} \mathrm{kg}^{-1}\right)$, and 51.6 of $\mathrm{K}\left(\mathrm{g} \mathrm{kg}^{-1}\right)$ with a $\mathrm{pH}$ of 8.5 , the dosage being $1.7 \mathrm{thm}^{-2}$ (dry weight basis). Twelve plots (4 treatments with 3 replicates) of size $5 \times 6 \mathrm{~m}^{2}$ were 
randomly distributed, having been used for double-rice and winter ryegrass rotation since 1986.

\section{Grain yields and dry matter}

The seeding rate for the rice was 200,000 seedling $/ \mathrm{hm}^{2}$ for both early and late rice. At maturity, three sites of $1 \mathrm{~m}^{2}$ were chosen randomly from each plot in order to determine the grain yield and dry matter. Plant samples were separated into straw and grain by a manually-operated thresher. The dry weight of roots, parts of above ground, and grain were determined after oven drying at $75^{\circ} \mathrm{C}$ to the constant weight. Panicles, spikelets per panicle, grain filling percentages (the filled spikelet number/total spikelet number $\times$ $100 \%$ ), and 1000-grain weights were estimated in order to calculate grain yield.

\section{Soil sampling and analysis}

The soils from the rhizosphere were sampled at time points standing for four growth stages: the early rice tilling stage, the early rice mature stage, the late rice tilling stage, and the late rice mature stage; these samplings were taken on May 7, July 7, August 4, and October 12 in 2016. Rhizosphere soil samples were collected as reported by Smalla et al. (2001). One composite sample was taken that consisted of roots of 5 random rice plants. The roots were shaken vigorously in order to separate soil not tightly adhering to its roots. The soils from rhizosphere were then collected, kept on ice, and stored, half of each sample at $-70{ }^{\circ} \mathrm{C}$ for soil DNA extraction, and the other half at $4{ }^{\circ} \mathrm{C}$ for soil microbial biomass.

Soil microbial biomass $\mathrm{C}(\mathrm{MBC})$ and $\mathrm{N}(\mathrm{MBN})$ were determined through fumigation with ethanol-free $\mathrm{CHCl}_{3}$ and extraction with $\mathrm{K}_{2} \mathrm{SO}_{4}$ (Vance et al., 1987), the organic $\mathrm{C}$ in the extracts was determined using an automated total organic $\mathrm{C}$ (TOC) analyzer (Shimadzu, TOC-Vwp, Japan), and the $\mathrm{N}$ was detected by the Kjeldahl method. Correction factors of $0.45\left(\mathrm{~K}_{\mathrm{EC}}\right)$ (Wu et al., 1990) and $0.57\left(\mathrm{~K}_{\mathrm{EN}}\right)$ (Jenkinson, 1988), were used for the calculated MBC and MBN values, respectively.

\section{DNA extraction, PCR, and DGGE analysis}

Three soil replicates were mixed, PCR and DGGE were run 3 times. Total microbial DNA was extracted from approximately $0.5 \mathrm{~g}$ of soil by using a Soil DNA Out Kit (TIANDZ, Beijing, China), following the manufacturer's instructions. The variable (V3) region of the $16 \mathrm{~S}$ rRNA gene was amplified by PCR using the primers of V357F-GC clamp

$\left(5^{\prime}-\right.$ CGCCCGCCGCGCGCGGCGGGCGGGGCGGGGGCACGGGGGGCCTACGGGAGG CAGCAG-3)' and V517R (5'-ATTACCGCGGCTGCTGG-3'), as described by Muyzer (1993). All amplifications were performed in $50 \mu \mathrm{l}$ of PCR reactions containing $2.5 \mathrm{ng}$ of template DNA, $1 \mu \mathrm{l}$ of each primer at $20 \mu \mathrm{M}, 4 \mu \mathrm{l}$ of $10 \mathrm{mM}$ dNTP, $2.5 \mathrm{U}$ of Taq DNA polymerase, $5 \mu \mathrm{l}$ of $10 \times \mathrm{PCR}$ buffer with $\mathrm{Mg}^{2+}$ supplied with Taq DNA polymerase (Takara BIO, Tokyo, Japan) and deionized-distilled $\mathrm{H}_{2} \mathrm{O}$. The following parameters were used for PCR amplification: initial denaturation for 3 min at $94{ }^{\circ} \mathrm{C}$, followed by 28 cycles of $30 \mathrm{~s}$ at $94{ }^{\circ} \mathrm{C}, 30 \mathrm{~s}$ at $59{ }^{\circ} \mathrm{C}$, and $1 \mathrm{~min} 30 \mathrm{~s}$ at $72{ }^{\circ} \mathrm{C}$, with a final extension step at $72^{\circ} \mathrm{C}$ for $10 \mathrm{~min}$. The PCR products were verified by electrophoresis in $1.5 \%$ agarose gels (containing $0.02 \%$ ethidium bromide) within $1 \times$ TAE buffer $(40 \mathrm{mM}$ Tris acetate, $1 \mathrm{mM}$ EDTA, $\mathrm{pH}$ 8.3). 
The DGGE analysis of microbial community structure was performed by using the DCode Universal Mutation Detection System (Bio-Rad Laboratories, Hercules, CA, USA). $13 \mu \mathrm{l}$ of PCR products (approx. $300 \mathrm{ng} \mu^{-1}$ ) and $7 \mu 1$ of loading buffer were loaded onto $6-12 \%(\mathrm{w} / \mathrm{v})$ polyacrylamide gels in $0.5 \mathrm{x}$ TAE buffer. The denaturing gradient was established with 30-50\% denaturant (100\% denaturant corresponding to $7 \mathrm{M}$ urea and $40 \%(\mathrm{v} / \mathrm{v})$ deionized formamide). Electrophoresis was performed at a constant voltage of $200 \mathrm{~V}$ for $5 \mathrm{~h}$ at $61^{\circ} \mathrm{C}$. The gel was stained by SYBRs Green I (Molecular Probes, Eugene, USA) for $30 \mathrm{~min}$, and scanned using the Alpha Imager 2200 Imaging System (Alpha Innotech, USA).

Specific and dominant bands in various treatments were excised from the DGGE gel and eluted overnight in a diffusion buffer at room temperature for re-amplification, as described above. Specific bands were those which were unique between each treatment, whereas dominant bands were those present with a high intensity. The amplified 16S rRNA gene segments were then inserted into pEASY-T3 vectors (TransGen Biotech, Beijing, China) and transformed into Escherichia coli DH5a. The recombinants were cultured in LB medium, from which white clones were randomly selected and inoculated in LB/Amp ${ }^{+}$, then sequenced by an ABI 3730XL DNA Sequencer (Perkin Elmer, USA) at the Sun Biotech Developing Center (Beijing).

The closest match to each sequence was obtained by using the NCBI basic local alignment search tool (http://www.ncbi.nlm.gov/blast/). The alignment of similar 16S rRNA gene sequences were conducted by Mega 5.

\section{Data analyses and statistics}

All results were based on three replications in the field. The data was subjected to analysis of means and standard deviations. The diversity analysis of DGGE patterns was conducted using Quantity One 4.2.3 software (Bio-Rad Laboratories, Hercules, CA, USA) by the unweighted pair-group method with arithmetic averages (UPGMA). Soil microbial community diversity was assessed by the Shannon-Weaver index $(\mathrm{H})$ and richness (S) according to the Equation 1 (Shannon, 1949), based on the number of bands and their intensities in each lane:

$$
H=-\sum_{i=1}^{s}\left(p_{i}\right)\left(\log 2 p_{i}\right)
$$

where $p_{i}$ is the relative intensity of the $i$ th band calculated as $p_{i}=\mathrm{n}_{i} / \mathrm{N}$, in which $\mathrm{n}_{i}$ is the intensity of the $i$ th band and $\mathrm{N}$ is the total intensity of all bands. Richness was recorded as the number of DGGE bands of each sample. The principal component analysis (PCA) of DGGE profiles was performed using the SAS 8.2 statistical program (SAS Institute Inc., Cary, USA). Statistical analyses were performed by one-way ANOVA followed by LSD multiple comparison tests of significance. A probability value $(P)$ of $<0.05$ was considered as statistically significant.

\section{Results}

\section{Bacterial community structure and diversity}

PCR-DGGE is a molecular fingerprinting method that allows direct comparative overview of the composition and diversity of dominant soil bacteria. DGGE has been 
used in many studies of environmental microorganisms, and proven a powerful method in investigating bacterial communities in rhizosphere soils (Qiao et al., 2012; Watanabe et al., 2004) since its first application (Muyzer et al., 1993). Soil samples from the 4 different growth stages of the control and 3 different fertilizer treatments were analyzed using PCR-DGGE in order to examine total microbial DNA.

In Figure 1, bands 1-25 stand for the common and specific clones of the bacterial species in the control and 3 different treatments. The twenty-five clones included 7 clones from NF, 5 clones from $\mathrm{CF}, 7$ clones from HRR, and 6 clones from the OCF treatment (Fig. 1). Bands at the same position of each lane were common bacterial specie in all treatments such as B15, but some bands were only present in one lane or several lanes, such as B1 in lanes 3 and 8, B22 in lanes 3 and 7, B25 in lane 13, etc. Naturally, these bands represent specific bacterial species in different treatments. The more bands that showed up in a given lane, the greater the richness of bacteria identified in the fields.

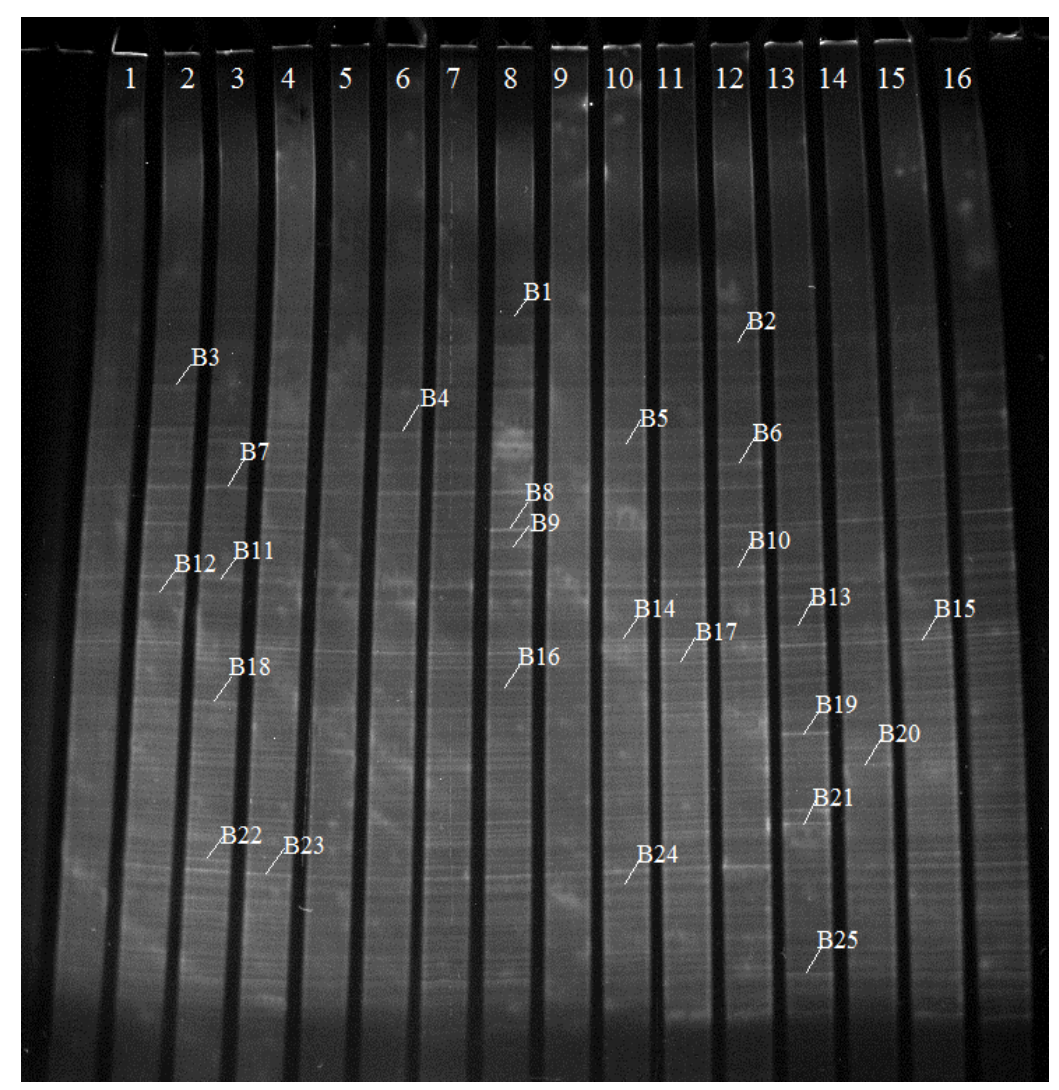

Figure 1. PCR-DGGE patterns of 16SrRNA gene fragments obtained from soil DNA extracted during four progressive rice growth stages in 2016: May 7, July 7, August 4, and October 12. Lane 1-4: no fertilizer (NF); lanes 5-8: chemical fertilizer (CF); lanes 9-12: harvested residue returned to soil (HRR); lanes 13-16: 60\% organic manure plus chemical fertilizer $(O C F)$. Letter $B$ followed by numbers indicates the bands that were extracted from the gel prior to sequencing analysis

Based on PCR-DGGE banding patterns, the Shannon-Weaver diversity index $(\mathrm{H})$ and corresponding richness $(\mathrm{S})$ were calculated (Table 1). Among the three treatments and control, HRR had the highest Shannon-Weaver index at stage 3 (3.88), while the lowest was OCF at stage 1 (3.04). 
Table 1. Shannon-Weaver diversity index $(H)$ and species richness $(S)$ of the bacterial community derived from the PCR-DGGE profiles

\begin{tabular}{c|c|c|c|c}
\hline Fertilization & $\begin{array}{c}\text { Date of soil } \\
\text { Sampling }\end{array}$ & Lane No. & Richness (S) & Shannon-Weaver (H) \\
\hline \multirow{4}{*}{ No fertilization (NF) } & May 07 & 1 & $47.21 \mathrm{e}$ & $3.70 \mathrm{a}$ \\
& July 07 & 2 & $53.15 \mathrm{a}$ & $3.71 \mathrm{a}$ \\
& Aug 04 & 3 & $51.33 \mathrm{~b}$ & $3.67 \mathrm{a}$ \\
& Oct 12 & 4 & $49.67 \mathrm{c}$ & $3.61 \mathrm{ab}$ \\
\hline & May 07 & 5 & $47.23 \mathrm{~d}$ & $3.43 \mathrm{~b}$ \\
Chemical fertilization & July 07 & 6 & $45.33 \mathrm{c}$ & $3.44 \mathrm{~b}$ \\
(CF) & Aug 04 & 7 & $49.51 \mathrm{~b}$ & $3.74 \mathrm{a}$ \\
& Oct 12 & 8 & $52.87 \mathrm{a}$ & $3.78 \mathrm{a}$ \\
\hline & May 07 & 9 & $45.33 \mathrm{c}$ & $3.67 \mathrm{~b}$ \\
Harvested residue & July 07 & 10 & $50.84 \mathrm{~b}$ & $3.73 \mathrm{~b}$ \\
returned to the soil & Aug 04 & 11 & $56.78 \mathrm{a}$ & $3.88 \mathrm{a}$ \\
(HRR) & Oct 12 & 12 & $49.51 \mathrm{~b}$ & $3.87 \mathrm{a}$ \\
\hline \multirow{3}{*}{ 60\% Organic manure } & May 07 & 13 & $46.32 \mathrm{c}$ & $3.04 \mathrm{c}$ \\
plus chemical & July 07 & 14 & $55.33 \mathrm{a}$ & $3.43 \mathrm{~b}$ \\
fertilization (OCF) & Aug 04 & 15 & $51.54 \mathrm{~b}$ & $3.75 \mathrm{a}$ \\
& Oct 12 & 16 & $46.32 \mathrm{c}$ & $3.80 \mathrm{a}$ \\
\hline
\end{tabular}

Means in each column by different letters are significantly different at $P<0.05$ level, $\mathrm{n}=3$. Lane No. was the number shown in Figure 1

Variance analysis between different stages in each group showed that the diversity of the bacterial community had a significant increase $(p<0.05)$ from the early rice stage to the late rice stage in three treatment groups, but not in the control group. Further, except for NF, bacterial community diversity generally increased with a given growth stage in three treatment groups, and increased dramatically from the early rice stage to late rice stage for OCF. This increase was from 3.04 to 3.80, although it should be noted that the index between the two stages of early rice (between early rice tilling and the mature stage) or the last rice stages (between late rice tilling and the mature stage) was not significant in the treatments (Table 1). This indicates that the bacterial communities in red paddy soil with various treatments matured from early rice to late rice.

\section{Dendrogram analysis}

In order to describe the integrated change of the bacterial community shown by $\mathrm{H}$ and $\mathrm{S}$ in response to fertilization regimes, PCA and UPGMA cluster analyses were used to compare the different effects of the four groups. PCA based on DGGE banding patterns separated the bacterial communities into two groups: NF and $\mathrm{CF}$ in one group, and OCF and HRR in another (Fig. 2). The first two principle components of the PCA plot accounted for $20 \%$ and $31 \%$ of the overall variance, respectively. However, sample 9 in the HRR group (May 2015) was clearly separated from the other two groups and could be considered an outlier. Possible reason for this is that sample 9 was in the early rice tilling stage of HRR, and harvested residue may cause something different to occur in the early days, which would need to be further studied. 


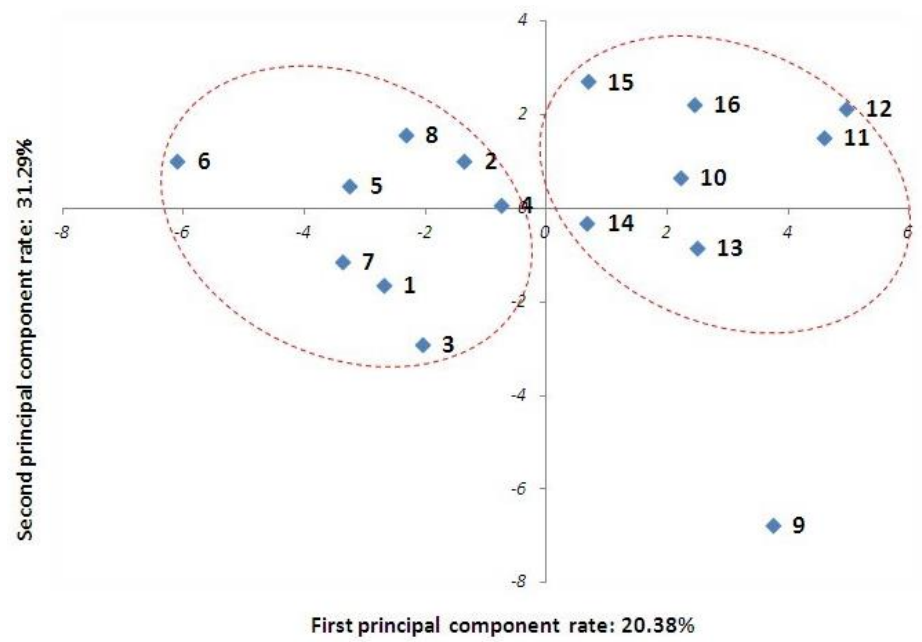

Figure 2. Principle component analysis (PCA) of microbial diversity indices of rhizosphere bacterial communities in different fertilization and growth stages based on DGGE profiles of bacterial 16s rRNA. The codes 1-16 are as defined in Table 1

In general, clustering analysis corroborated the visual interpretation of the DGGE profiles. A dendrogram was obtained using the UPGMA clustering analysis, and the similarity coefficient of Pearson was based on the DGGE profiles of bacterial 16s rRNA gene fragments (170 bp). The clustering analysis revealed that two clusters were separated at 54\% similarity, eliminating outlier sample 9. One cluster included samples from HRR and OCF, while another included samples from NF and CF. This suggests that DGGE patterns of CF soil are similar to that of NF soil at all growth stages, while the bacterial community of HRR soil is more similar to that in OCF soil (Fig. 3).

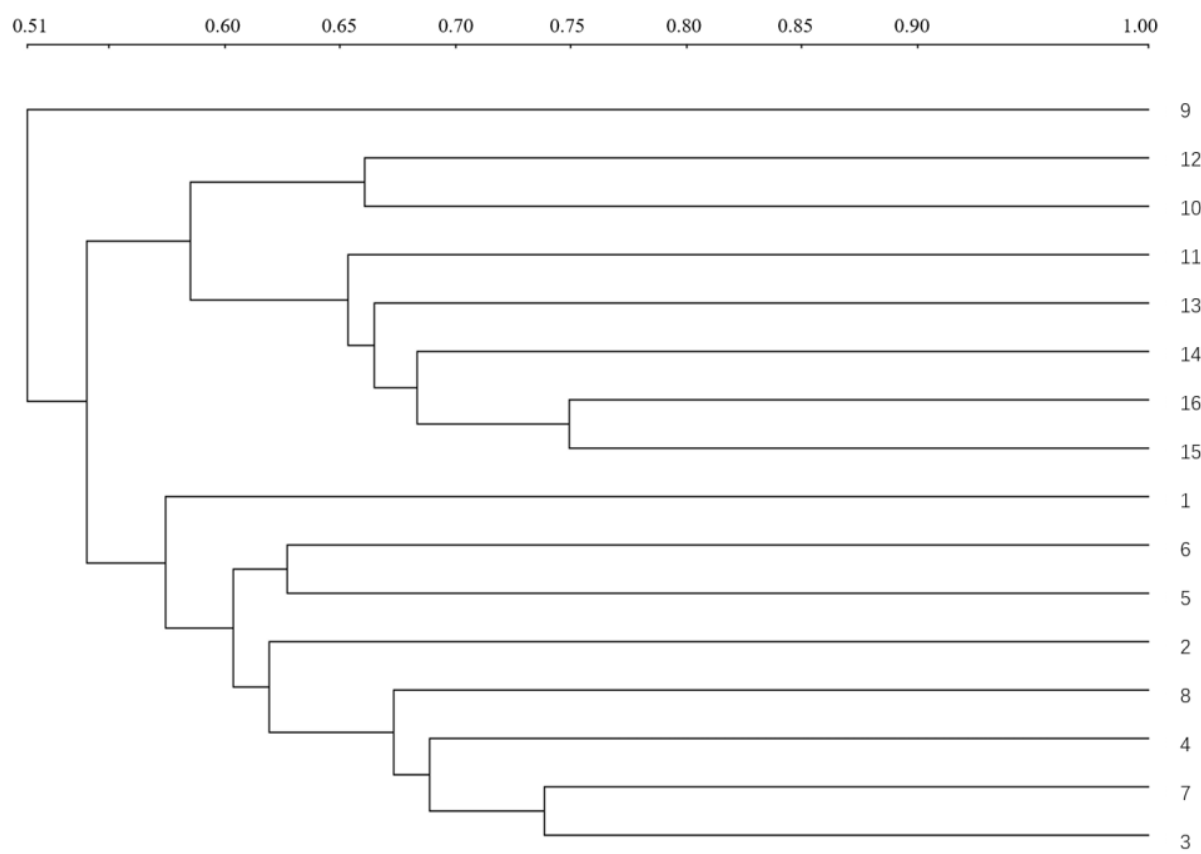

Figure 3. UPGMA clustering represents the similarity of $16 S$ rRNA gene fragments from PCR$D G G E$ profiles generated from soil DNA extracted from different fertilizations and growth stages. The codes $1-16$ are as defined in Table 1 
At $65 \%$ similarity, the soil samples representing the HRR group separated from those of OCF. Four growth stages in the OCF group clustered together, but the growing stages of NF and CF were not separated, which indicates that the difference between the bacterial community structure of NF and CF was not as distinct as that between HRR and OCF.

\section{Sequenced bacterial bands and phylogenetic analysis}

Twenty-five specific and intensive bands were excised from the DGGE gel (16S rRNA), then re-amplified, transformed, and sequenced to identify dominant bacterial populations in various soil samples. The 16S rRNA gene sequences (170 bp) of the 25 clones were submitted to the NCBI nucleotide sequence database (Table Al in the Appendix). Since more than $50 \%$ of the retrieved sequences were closely related to $16 \mathrm{~S}$ rRNA genes of uncultured bacteria, the first hit in Blast-N matching to a culturable strain was also considered. These sequences were classified into eight phyla: Proteobacteria (B5, B6, B7, B9, B10, B14, B15, B16, B17, and B18), Gemmatimonadetes (B11 and B20), Chloroflexi (B22, B23, and B24), Acidobacteria (B1, B3, B13, and B19), Actinobacteria (B8, B12, and B25), Firmicutes (B4), Bacteroidetes (B2), and Planctomycete (B21) (Table 2).

Table 2. Sequence identification of $16 S$ rRNA gene fragments retrieved from DGGE bands by NCBI blast $-N$

\begin{tabular}{|c|c|c|c|}
\hline $\begin{array}{l}\text { 16s rDNA } \\
\text { fragments }\end{array}$ & Bacteria with the highest identity & $\begin{array}{l}\text { The highest } \\
\text { identity (\%) }\end{array}$ & Phylum \\
\hline B1 & Acidobacteria bacterium (EF417700.1) & 100 & Acidobacteria \\
\hline $\mathbf{B 2}$ & Uncultured Sphingobacteria bacterium (EU299921.1) & 93 & Bacteroidetes \\
\hline B3 & Acidobacteriales (EU193004.1) & 98 & Acidobacteria \\
\hline B4 & Uncultured Firmicutes bacterium (EU753610.1) & 100 & Firmicutes \\
\hline B5 & Proteobacterium (EU298752.1) & 100 & Proteobacteria \\
\hline B6 & Uncultured beta proteobacterium (AB748625.1) & 98 & Proteobacteria \\
\hline B7 & Uncultured Rhizobiales bacterium (FJ477663.1) & 100 & Proteobacteria \\
\hline B8 & Uncultured Actinomycetales bacterium (EU449558.1) & 95 & Actinobacteria \\
\hline B9 & Uncultured Bradyrhizobium sp. (JX505261.1) & 98 & Proteobacteria \\
\hline B10 & Uncultured delta proteobacterium (FJ902393.1) & 100 & Proteobacteria \\
\hline B11 & Uncultured Gemmatimonadetes bacterium (EU297425.1) & 98 & Gemmatimonadetes \\
\hline B12 & Mycobacterium bovis (AP010918.1) & 100 & Actinobacteria \\
\hline B13 & Acidobacterium sp. (GQ287545.1) & 92 & Acidobacteria \\
\hline B14 & Uncultured delta proteobacterium (FJ902063.1) & 100 & Proteobacteria \\
\hline B15 & Uncultured Novosphingobium sp. (JQ701055.1) & 95 & Proteobacteria \\
\hline B16 & delta proteobacterium (GQ406161.1) & 91 & Proteobacteria \\
\hline B17 & delta proteobacterium (JQ795294.1) & 100 & Proteobacteria \\
\hline B18 & Uncultured alpha proteobacterium (KC449494.1) & 100 & Proteobacteria \\
\hline B19 & Uncultured Acidobacteria bacterium (AM935771.1) & 98 & Acidobacteria \\
\hline B20 & Gemmatimonadetes bacterium (EF074631.1) & 100 & Gemmatimonadetes \\
\hline B21 & Planctomycete (GQ443701.1) & 100 & Planctomycete \\
\hline B22 & Chloroflexi (AY149071.1) & 95 & Chloroflexi \\
\hline B23 & Uncultured Chloroflexi bacterium (GQ366653.1) & 94 & Chloroflexi \\
\hline B24 & Uncultured Chloroflexi (JQ4021491) & 91 & Chloroflexi \\
\hline B25 & Uncultured Actinobacteridae bacterium (KC018166.1) & 99 & Actinobacteria \\
\hline
\end{tabular}


The relative abundance of dominant bacterial phylum taxa in the control and three treatments are shown in Figure 4. All eight bacterial phyla could be detected in the fertilization treatments except for $\mathrm{CF}$, in which Planctomycete was not detected in all growing stages. It was clear that the abundance of each bacterial phyla showed explicit differences among the treatments. Proteobacteria was the most abundant bacteria under various treatments, with relative abundance ranging from 31 to $48 \%$. More, relative abundance of Planctomycete and Acidobacteria were greater in the HRR and OCF groups as compared to NF and CF. On the contrary, Gemmatimonadetes decreased in HRR and OCF treatments. A hierarchical heatmap of bacterial phyla separated the samples into two groups, with 10,11,12,13,15 and 16 grouped together, the other samples grouped together. In the first group, all samples were from HRR and OCF, in the other group, most of samples from NF and CF, except 9 and 14 (Fig. 5).

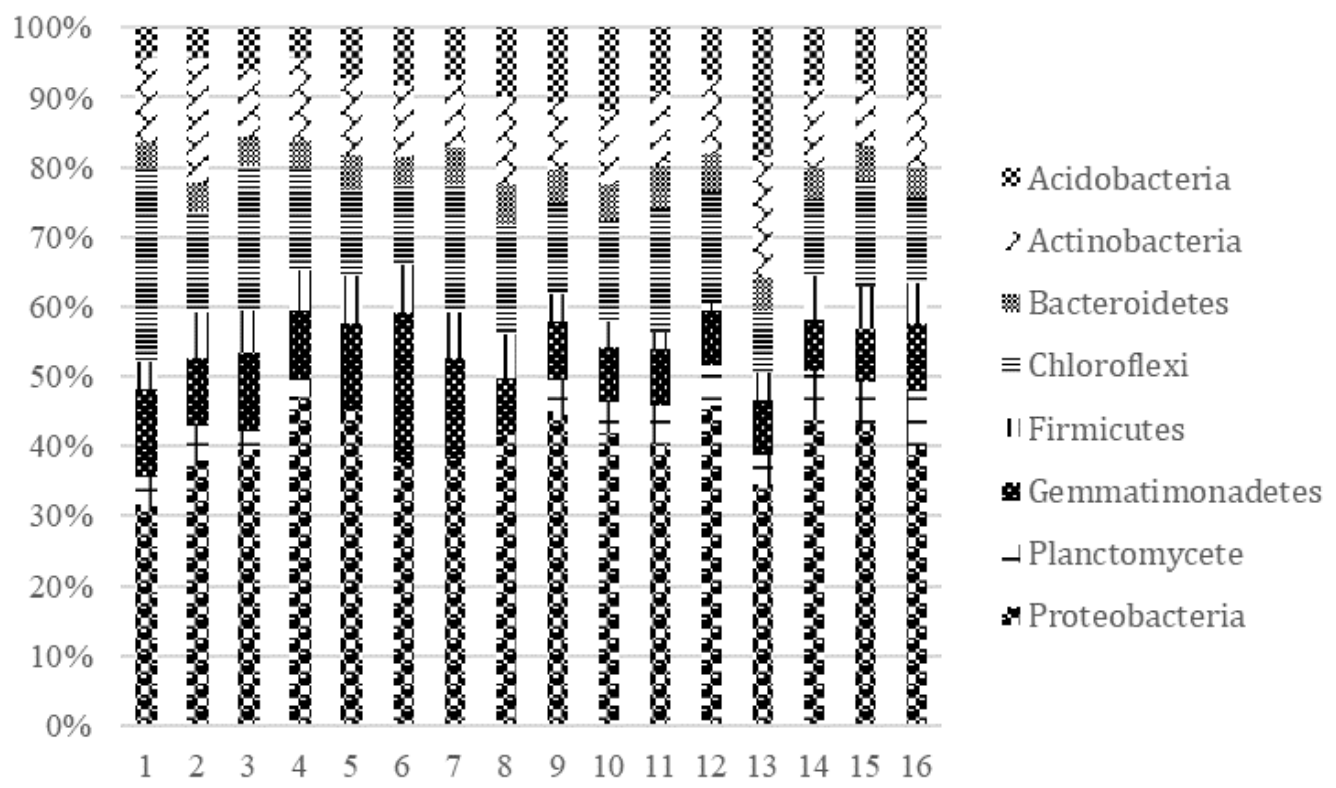

Figure 4. The relative abundance of all detected phyla in different fertilizations and growth stages treatments. The codes $1-16$ are as defined in Table 1

\section{Soil microbial biomass and crop yields}

Plants depend on rhizosphere microbiota to make nutrients accessible. The above data showed that rhizosphere microbiota varied across the fertilizer treatments. In order to examine whether different fertilizers affect both soil quality and crop yields, soil biomass, grain yields, and dry matter were evaluated.

Soil MBN was significantly higher $(P<0.05)$ in HRR and OCF than in CF and NF during the sampling period, whereas MBC was significantly higher $(P<0.05)$ only in May and Oct. Both MBN and MBC did not differ significantly between $\mathrm{CF}$ and NF in all stages, but there was a difference between OCF and HRR (Table 3). Further, MBN was significantly higher in OCF than in HRR in July and October, while MBC in OCF was significantly higher in May but lower in Oct than HRR. These results indicate that different fertilizer treatments resulted in different values for MBC and MBN, especially fertilizers with organic components such as HRR and OCF, which in turn led to significantly higher biomass in the soils compared to CF or NF. 


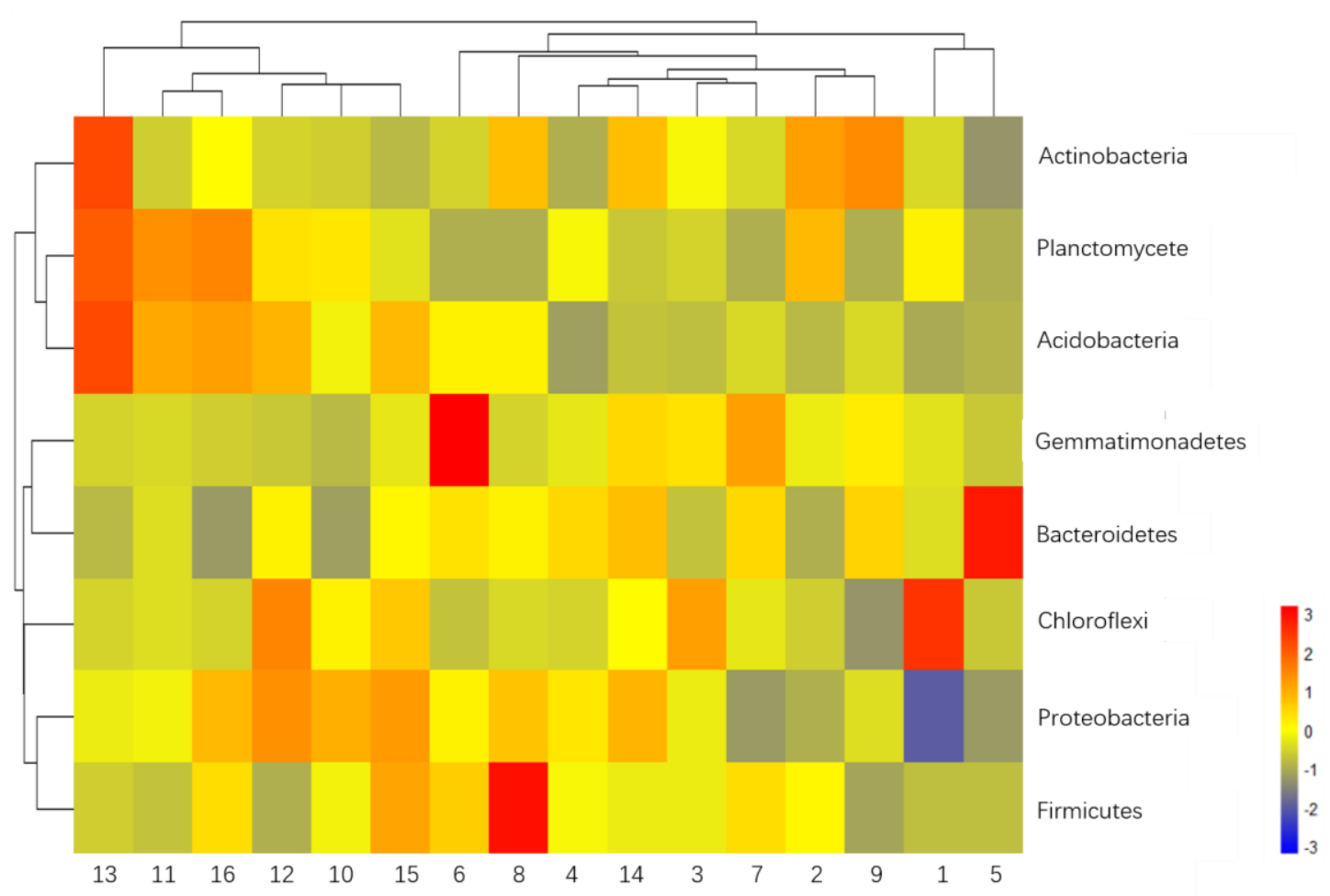

Figure 5. Distribution of the phyla and their cluster analysis in different fertilizations and growth stages as visualised by heatmaps (variables clustering on the vertical axis). The relative abundances for microbial phyla are indicated by colour intensity. The codes 1-16 are as defined in Table 1

Table 3. Effect of different fertilizations on soil microbial biomass $C(M B C)$ and soil microbial biomass $N(M B N)$

\begin{tabular}{|c|c|c|c|c|c|c|}
\hline & Treatment & May 07 & Jul 07 & Aug 04 & Oct 12 & Average \\
\hline \multirow{4}{*}{$\begin{array}{c}\mathrm{MBC} \\
\left(\mathrm{mg}^{\mathrm{kg}} \mathrm{kg}^{-1}\right)\end{array}$} & NF & $145.7 \mathrm{c}$ & $210.6 b$ & $266.2 \mathrm{a}$ & $263.4 b$ & $221.5 b$ \\
\hline & $\mathrm{CF}$ & $150.2 \mathrm{c}$ & $209.5 b$ & $268.2 \mathrm{a}$ & $267.1 \mathrm{~b}$ & $223.8 b$ \\
\hline & HRR & $185.4 \mathrm{~b}$ & $238.2 \mathrm{a}$ & $269.3 \mathrm{a}$ & $330.0 \mathrm{a}$ & $255.7 \mathrm{a}$ \\
\hline & $\mathrm{OCF}$ & $256.4 \mathrm{a}$ & $215.5 \mathrm{ab}$ & $267.6 \mathrm{a}$ & $287.8 \mathrm{~b}$ & $256.8 \mathrm{a}$ \\
\hline \multirow{4}{*}{$\begin{array}{c}\mathrm{MBN} \\
\left(\mathrm{mg} \cdot \mathrm{kg}^{-1}\right)\end{array}$} & $\mathrm{NF}$ & $7.5 b$ & $6.8 \mathrm{c}$ & $3.3 b$ & $9.5 \mathrm{c}$ & $6.8 b$ \\
\hline & $\mathrm{CF}$ & $7.9 \mathrm{~b}$ & $8.0 \mathrm{c}$ & $3.9 \mathrm{~b}$ & $11.2 \mathrm{c}$ & $7.8 \mathrm{~b}$ \\
\hline & HRR & $13.8 \mathrm{a}$ & $16.4 \mathrm{~b}$ & $6.8 \mathrm{a}$ & $18.8 \mathrm{~b}$ & $14.0 \mathrm{a}$ \\
\hline & $\mathrm{OCF}$ & $15.4 \mathrm{a}$ & $18.9 \mathrm{a}$ & $6.3 \mathrm{a}$ & $22.0 \mathrm{a}$ & $15.6 \mathrm{a}$ \\
\hline
\end{tabular}

Means in each column within MBC and MBN followed by different letters are significantly different at $P<0.05$ level, $\mathrm{n}=3$. NF: no fertilizer, $\mathrm{CF}$ : chemical fertilizer; HRR: harvested residue returned to soil; OCF: $60 \%$ organic manure plus chemical fertilizer

Double rice total grain yield (i.e. the sum of early and late rice grain yield) in all three treatments were significantly higher than that in NF plots. Among the fertilizer treatments, the grain yield of OCF plots was highest $(P<0.05)$, there being no significant difference between $\mathrm{CF}$ and HRR. Compared to NF, grain yields of $\mathrm{CF}, \mathrm{HRR}$, and OCF were increased by $26.5 \%, 26.5 \%$, and $38.9 \%$, respectively (Table 4). Further, 
dry matter in OCF plots was highest. Compared to NF, dry root weight of CF, HRR, and OCF were increased by $40.6 \%, 29.9 \%$, and $50.8 \%$; similarly, the above ground weights were increased by $36.0 \%, 29.4 \%$, and $44.4 \%$.

Table 4. Rice grain yield and dry matter of double rice by different fertilizations

\begin{tabular}{|c|c|c|c|}
\hline \multirow{2}{*}{ Treatment } & \multirow{2}{*}{ Yield $\left(\mathrm{kg.hm}^{-2}\right)$} & \multicolumn{2}{|c|}{ Dry matter (kg.hm-2 } \\
\hline & & Root & Above ground \\
\hline $\mathrm{NF}$ & $9001.2 \mathrm{c}$ & $837.3 c$ & $15543.4 d$ \\
\hline $\mathrm{CF}$ & $11391.5 b$ & $1177.5 \mathrm{ab}$ & $21142.0 \mathrm{~b}$ \\
\hline HRR & $11392.6 b$ & $1087.6 \mathrm{~b}$ & $20120.3 c$ \\
\hline $\mathrm{OCF}$ & $12503.5 a$ & $1262.9 \mathrm{a}$ & $22448.2 \mathrm{a}$ \\
\hline
\end{tabular}

Means in each column followed by different letters are significantly different at $P<0.05$ level, $\mathrm{n}=3$. NF: no fertilizer, CF: chemical fertilizer; HRR: harvested residue returned to soil; OCF: $60 \%$ organic manure plus chemical fertilizer

\section{Discussion}

In this study, we assessed the structure of microbial communities in response to three types of fertilization on different stages of growth. Broadly, the structure and composition of the bacterial communities were grouped into two clusters: chemical fertilization (CF) and the control treatments in one group, and HRR and OCF in the other (Fig. 2).

Previous studies demonstrate that the activity and diversity of soil microorganisms are directly influenced by changes such as soil temperature (Fierer et al., 2005), moisture (Hollister et al., 2010), pH (Rousk et al., 2010), nutrient availability (Cusack et al., 2011), soil type (Xu et al., 2009), and plant type (Berg et al., 2006); following that fertilization is one of the most significant anthropogenic activities that greatly alter soil characteristics. Many studies showed that fertilizers, regardless of type, affect soil bacterial community structure (Enwall et al., 2007; Gu et al., 2009; Marschner et al., 2003). We've concluded that HRR and OCF showed similar influences on soil bacterial communities, but that CF soil had a similar bacterial community structure as NF. Chu et al. previously concluded similar results, in which inorganic fertilization did not affect the DGGE banding pattern (Chu et al., 2007). In contrast, higher bacterial community diversity and structure change were observed in soils with chemical plus organic rice straw treatments in double rice cropping system by using 16S rRNA sequencing (Wu et al., 2011; Yuan et al., 2013), although it should be noted that manure and chemical fertilizers did not change the bacterial community structure significantly in maize or wheat cropping system (Ge et al., 2008; Shen et al., 2010).

In our study, both microbial community diversity and biomass of CF soils were similar to that of NF soils, but were significantly different from that of OCF and HRR soils (Tables 1 and 3). A possible reason for this is that organic matter in OCF and HRR provide available substrates for microbial growth and further, that there is a positive correlation between $\mathrm{MBC}$ and soil organic matter, as previously reported ( $\mathrm{Wu}$ et al., 2013).

Compared to inorganic fertilizers, organic fertilizers diversify bacterial communities. Previous studies have found that soil organic matter exerted significant influence on the diversity and structure of soil microorganisms (Cusack et al., 2011; Gu et al., 2009; Hartmann et al., 2015). This is consistent with our results, as HRR and OCF increased 
the diversity of bacterial communities in soil. Moreover, the diversity of bacterial communities with HRR was highest because straw, the most natural and suitable organic resource of the energy for bacterial activities in soils, was found in greater amounts. Additionally, soil was found to be healthier when straws were returned to fields in HRR (Lou et al., 2011).

Likewise, OCF treatment greatly increased organic substances and adjusted the balance of carbon and nitrogen in soils, both beneficial to soil microbes (Chen et al., 2017). However, OCF showed lower bacterial diversity than HRR, which might be due to its combination with chemical fertilizer. Overall, our results indicated that HRR was the best fertilizer practice, measured as bacterial community diversity against $\mathrm{CF}$ and OCF.

In previous studies, microbial diversity and community structure in rice field soils have been reported to change with season and fertilizer management practices (Ahn et al., 2012; Doi et al., 2011). Except for NF, we have found that the growth stages of rice affect bacterial diversity (Table 1). Further, the diversity of CF and OCF in two late growth stages were significantly higher than those at the two early stages, while not varying much between early and late stages in HRR. We theorize that $\mathrm{CF}$ and OCF having more evident effects than HRR may be that HRR diversified the microbe community quickly then keeping bacterial richness steady at a high level, thus leading to less notable effects with growth stages. Further, diversity at the start of the early stage was low, but significantly increased at the late stage in OCF, which could be explained by OCF being a slow-release fertilizer. Additionally, variation of bacterial communities in various growth stages is also indirectly related to environmental characteristics and root exudates (Tian et al., 2013). However, the influences of these factors are lower than direct fertilizer application.

Our results demonstrated that the dominant bacterial species in these four groups belonged to eight phyla (Table 2; Fig. 4). The eight phyla identified were the same as those detected in rice soils by means of pyrosequencing (Ahn et al., 2012). Two of these were Gram-positive bacteria (Firmicutes and Actinobacteria), the others being Gramnegative. Hence, the predominant bacteria in rice rhizosphere were Gram-negative bacteria, especially Proteobacteria, irrespective of soil type and growth stage. Moreover, the microbial community possessing more Gram-negative bacteria was found to be more active as well as relatively stable and resilient (Peng et al., 2016). These findings are consistent with DGGE analysis results from Ikenaga et al. (2003).

Acidobacteria usually functions in biogeochemical cycling of carbon and is more abundant in acidic soils (Sait et al., 2006). The increase of Acidobacteria in fertilizer treatment groups compared to the control group may be explained by CF's decreased $\mathrm{pH}$ of soils that made them more acidic. Meanwhile, HRR and OCF increased soil organic carbon and its production. Previous studies have demonstrated that Planctomyces is a marine bacterium existing in habitats rich with organic nutrients and oxidizing ammonium. Our study demonstrated that Planctomycete did not exist at all in $\mathrm{CF}$ treated soils, further suggesting that inorganic components in $\mathrm{CF}$ are not suitable for this type of bacteria. Therefore, HRR and OCF but not CF provided organic matter that promoted Planctomycete growth. Moreover, compared to NF treated soil, organic fertilizers demonstrated significantly lower soil bulk density (Rasool et al., 2008), which make soils more suitable for the survival of planctomycete.

Last, the decline of the relative abundance of Gemmatimonadetes in HRR and OCF was probably due to their preference for drier soils. Gemmatimonadetes have been 
found in a variety of arid soils, so it tends to be more dependent on the moisture availability than aggregation (DeBruyn et al., 2011). Organic matter lead to soil aggregation, and thus dryness-favored bacterial Gemmatimonadetes decreased. The moisture-favored bacterial Planctomyces, by contrast, increased in HRR and OCF.

Rice is the most important crop in China, thus, fertilization is an important agricultural practice for increasing crop yields. Traditionally, farmers have used organic fertilizer such as manure and crop residues to maintain soil fertility. However, chemical fertilizers have increasingly been applied to rice paddies in China as of the 1980s. This has been done in order to meet food demand of increasing populations, primarily because inorganic fertilizers directly boost crop yields and are more affordable. Consequently, fewer organic fertilizers are currently used, and large chemical fertilizer input has caused soil acidity major croplands (Guo et al., 2010).

Long-term fertility experiments provide insight into the consequences of land management strategies. In our study, compared to other fertilizers, OCF improves both grain yields and soil biomass; this is due to the combination of organic manure and chemical fertilizer, in which chemical $\mathrm{P}$ availability plays a vital role in improving rice productivity as what Ding et al. (2018) recently reported. Moreover, previous studies demonstrated that $\mathrm{P}, \mathrm{N}$, and $\mathrm{MBC}$ increased in soils with organic manure treatment, significantly improving rice yields and microbial activity (Zheng et al., 2016). However, the grain yields of CF (containing chemical P) and HRR (containing organic straw residuals) were not significantly different, indicating that the combination of both organic and inorganic fertilizers is the best method to improve grain yield.

Similarly, previous studies have demonstrated that chemical $\mathrm{N}$ increased in HRR but that chemical P did not change (Zheng et al., 2016). Further, it has been demonstrated that $\mathrm{N}$ fertilization promoted crop productivity only after following the supplement of $\mathrm{P}$ (Lv et al., 2011), which explains why CF or HRR did not promote significant grain yields. Although HRR has similar effects as chemical fertilizer (CF) on grain yield, HRR had more beneficial effects on soil sustainability, such as increased microbial diversity and biomass (Table 3).

Generally, soil microbial biomass plays an important role in maintaining soil structure, facilitating microbial metabolic processes, and regulating the release of nutrients. Our results suggest that OCF and HRR had similar MBC and MBN (Table 3), and thus similar microbial community structures (Figs. 2 and 3). However, our results also suggest that OCF has more advantages on improving grain yields, while HRR is more beneficial to soil quality and microbial structures.

In sum, chemical fertilizer plays an important role in increasing yield, but large fertilizer input in the field usually causes environmental problems. This has become a major concern for scientists, environmental groups, and agricultural policymakers worldwide. Figuring out how to assess and design healthy fertilizer practices that achieve optimum yields and maintain soil sustainability is challenging, and it will be our focus in future studies.

\section{Conclusions}

This study has reported the effects of three long-term fertilization treatments $(\mathrm{CF}$, HRR, and OCF) on bacterial community structure and abundance at different rice growth stages of red paddy soils in southern China. It has also reported the corresponding microbial biomass and grain yields. PCR-DGGE results revealed that 
among the three fertilizer practices, both HRR and OCF showed positive and lasting effects on soil quality, but that the soil microbial community in HRR was steadiest and most diverse. The bacterial diversity of OCF was next after HRR, with OCF demonstrating lasting effects on the bacterial community with growth stages.

The bacterial species belonged to 8 different phyla, and the abundance of each phylum of bacteria changed with various treatments. Planctomycete was not present in the $\mathrm{CF}$ group, suggesting the lower bacterial diversity in CF. HRR and OCF treatments significantly increased soil micro biomass compared to $\mathrm{NF}$, whereas $\mathrm{CF}$ did not. Furthermore, OCF with both inorganic and organic compositions promoted dry matter and total grain yield compared to any other treatment.

Overall, HRR is the fertilizer that best increases bacterial diversity in red paddy soils, whereas OCF is the best to promote crop yield. Broadly, this study has provided insights into the impact of different fertilizers on rhizospheric bacterial community structure, soil quality, and crop yield, providing critical information in selecting the optimal fertilization treatment. Further studies should focus on the application of combined inorganic and organic fertilizers, and balancing the economic and environmental benefits between crop yields and soil sustainability.

Acknowledgements. This research was funded by Shanxi Nonggu Establish Research Earmarked fund (No. SXNGJSKYZX201704), Shanxi Scholarship Council of China (No. 2016-068), and Shanxi Provincial Natural Science Foundation for Youths (No.201701D221181).

Conflicts of interests. The authors declare that they have no conflicts of interests.

\section{REFERENCES}

[1] Ahn, J. H., Song, J., Kim, B. Y., Kim, M. S., Joa, J. H., Weon, H. Y. (2012): Characterization of the bacterial and archaeal communities in rice field soils subjected to long-term fertilization practices. - J Microbiol 50: 754-765.

[2] Berg, G., Opelt, K., Zachow, C., Lottmann, J., Gotz, M., Costa, R., Smalla, K. (2006): The rhizosphere effect on bacteria antagonistic towards the pathogenic fungus Verticillium differs depending on plant species and site. - Fems Microbiology Ecology 56: $250-261$.

[3] Chen, D., Yuan, L., Liu, Y., Ji, J., Hou, H. (2017): Long-term application of manures plus chemical fertilizers sustained high rice yield and improved soil chemical and bacterial properties. - Eur J Agron 90: 34-42.

[4] Chu, H., Lin, X., Fujii, T., Morimoto, S., Yagi, K., Hu, J., Zhang, J. (2007): Soil microbial biomass, dehydrogenase activity, bacterial community structure in response to long-term fertilizer management. - Soil Biology and Biochemistry 39: 2971-2976.

[5] Cusack, D. F., Silver, W. L., Torn, M. S., Burton, S. D., Firestone, M. K. (2011): Changes in microbial community characteristics and soil organic matter with nitrogen additions in two tropical forests. - Ecology 92: 621-632.

[6] Debruyn, J. M., Nixon, L. T., Fawaz, M. N., Johnson, A. M., Radosevich, M. (2011): Global biogeography and quantitative seasonal dynamics of Gemmatimonadetes in soil. Appl Environ Microbiol 77: 6295-6300.

[7] Ding, L. J., Su, J. Q., Sun, G. X., Wu, J. S., Wei, W. X. (2018): Increased microbial functional diversity under long-term organic and integrated fertilization in a paddy soil. Applied Microbiology and Biotechnology 102: 1969-1982. 
[8] Dobermann, A., Dawe, D., Roetter, R. P., Cassman, K. G. (2000): Reversal of rice yield decline in a long-term continuous cropping experiment. - Agron Horticul-Faculty Publications 92: 633-643.

[9] Doi, T., Abe, J., Shiotsu, F., Morita, S. (2011): Study on rhizosphere bacterial community in lowland rice grown with organic fertilizers by using PCR-denaturing gradient gel electrophoresis. - Plant Root 5: 5-16.

[10] Enwall, K., Nyberg, K., Bertilsson, S., Cederlund, H., Stenström, J., Hallin, S. (2007): Long-term impact of fertilization on activity and composition of bacterial communities and metabolic guilds in agricultural soil. - Soil Biology and Biochemistry 39: 106-115.

[11] Fierer, N., Craine, J. M., Mclauchlan, K., Schimel, J. P. (2005): Litter quality and the temperature sensitivity of the decomposition. - Ecology 86: 320-326.

[12] Fierer, N., Lauber, C. L., Ramirez, K. S., Zaneveld, J., Bradford, M. A., Knight, R. (2012): Comparative metagenomic, phylogenetic and physiological analyses of soil microbial communities across nitrogen gradients. - ISME J 6: 1007-1017.

[13] Gao, S. J., Zhang, R. G., Cao, W. D., Fan, Y. Y., Gao, J. S., Huang, J., Bai, J. S., Zeng, N. H., Chang, D. N., Yoshi, S. K., Kristensen, K. T. (2015): Long-term rice-rice-green manure rotation changing the microbial communities in typical red paddy soil in South China. - J Integr Agr 14: 2512-2520.

[14] Ge, Y., Zhang, J. B., Zhang, L. M., Yang, M., He, J. Z. (2008): Long-term fertilization regimes affect bacterial community structure and diversity of an agricultural soil in northern China. - Journal of Soils and Sediments 8: 43-50.

[15] Gong, W., Yan, X., Wang, J., Hu, T., Gong, Y. (2009): Long-term manure and fertilizer effects on soil organic matter fractions and microbes under a wheat-maize cropping system in northern China. - Geoderma 149: 318-324.

[16] Gu, Y., Zhang, X., Tu, S., Lindström, K. (2009): Soil microbial biomass, crop yields, and bacterial community structure as affected by long-term fertilizer treatments under wheatrice cropping. - Eur J Soil Biol 45: 239-246.

[17] Guo, J. H., Liu, X. J., Zhang, Y., Shen, J. L., Han, W. X., Zhang, W. F., Christie, P., Goulding, K. W., Vitousek, P. M., Zhang, F. S. (2010): Significant acidification in major Chinese croplands. - Science 327: 1008-1010.

[18] Hartmann, M., Frey, B., Mayer, J., Mader, P., Widmer, F. (2015): Distinct soil microbial diversity under long-term organic and conventional farming. - ISME J 9: 1177-1194.

[19] Hollister, E. B., Engledow, A. S., Hammett, A. J. M., Provin, T. L., Wilkinson, H. H., Gentry, T. J. (2010): Shifts in microbial community structure along an ecological gradient of hypersaline soils and sediments. - The ISME Journal 4: 829.

[20] Ikenaga, M., Asakawa, S., Muraoka, Y., Kimura, M. (2003): Bacterial communities associated with nodal roots of rice plants along with the growth stages: Estimation by PCR-DGGE and sequence analyses. - Soil Science and Plant Nutrition 49: 591-602.

[21] Jenkinson, D. S. (1988): Determination of Microbial Biomass Carbon and N in Soil. - In: Wilson, J. R. (ed.) Advances in N Cycling in Agricultural Ecosystems. CAB Wallingford, London.

[22] Karlen, D. L., Ditzler, C. A., Andrews, S. S. (2003): Soil quality: why and how? Geoderma 114: 145-156.

[23] Kennedy, A. C. (1999): Bacterial diversity in agroecosystems. - Agr Ecosyst Environ 74: 65-76.

[24] Lou, Y., Xu, M., Wang, W., Sun, X., Zhao, K. (2011): Return rate of straw residue affects soil organic $\mathrm{C}$ sequestration by chemical fertilization. - Soil Till Res 113: 70-73.

[25] Lv, M., Li, Z., Che, Y., Han, F. X., Liu, M. (2011): Soil organic C, nutrients, microbial biomass, and grain yield of rice (Oryza sativa L.) after 18 years of fertilizer application to an infertile paddy soil. - Biology and Fertility of Soils 47: 777-783.

[26] Marschner, P., Kandeler, E., Marschner, B. (2003): Structure and function of the soil microbial community in a long-term fertilizer experiment. - Soil Biology and Biochemistry 35: 453-461. 
[27] Mooshammer, M., Wanek, W., Hämmerle, I., Fuchslueger, L., Hofhansl, F., Knoltsch, A., Schnecker, J., Takriti, M., Watzka, M., Wild, B., Keiblinger, K. M., ZechmeisterBoltenstern, S., Richter, A. (2014): Adjustment of microbial nitrogen use efficiency to carbon:nitrogen imbalances regulates soil nitrogen cycling. - Nature Commun 5: 3694.

[28] Muyzer, G., De Waal, E. C., Uitterlinden, A. G. (1993): Profiling of complex microbial populations by denaturing gradient gel electrophoresis analysis of polymerase chain reaction-amplified genes coding for $16 \mathrm{~S}$ rRNA. - Applied and Environmental Microbiology 59: 695-700.

[29] Peng, C., Lai, S., Luo, X., Lu, J., Huang, Q., Chen, W. (2016): Effects of long term rice straw application on the microbial communities of rapeseed rhizosphere in a paddyupland rotation system. - Science of the Total Environment 557-558: 231-239.

[30] Qiao, Y. J., Li, Z. Z., Wang, X., Zhu, B., Hu, Y. G., Zeng, Z. H. (2012): Effect of legume-cereal mixtures on the diversity of bacterial communities in the rhizosphere. Plant Soil \& Environment 58: 174-180.

[31] Rasool, R., Kukal, S. S., Hira, G. S. (2008): Soil organic carbon and physical properties as affected by long-term application of FYM and inorganic fertilizers in maize-wheat system. - Soil Till Res 101: 31-36.

[32] Rousk, J., Baath, E., Brookes, P. C., Lauber, C. L., Lozupone, C., Caporaso, J. G., Knight, R., Fierer, N. (2010): Soil bacterial and fungal communities across a pH gradient in an arable soil. - ISME J 4: 1340-1351.

[33] Sait, M., Davis, K. E., Janssen, P. H. (2006): Effect of pH on isolation and distribution of members of subdivision 1 of the phylum Acidobacteria occurring in soil. - Applied and Environmental Microbiology 72: 1852-1857.

[34] Shannon, C. E., (1949): The mathematical theory of communication. - University of Illinois Press, Urbana.

[35] Shen, J. P., Zhang, L. M., Guo, J. F., Ray, J. L., He, J. Z. (2010): Impact of long-term fertilization practices on the abundance and composition of soil bacterial communities in Northeast China. - Appl Soil Ecol 46: 119-124.

[36] Smalla, K., Wieland, G., Buchner, A., Zock, A., Parzy, J., Kaiser, S., Roskot, N., Heuer, H., Berg, G. (2001): Bulk and rhizosphere soil bacterial communities studied by denaturing gradient gel electrophoresis: plant-dependent enrichment and seasonal shifts revealed. - Applied and Environmental Microbiology 67: 4742-4751.

[37] Tian, J., Dippold, M., Pausch, J., Blagodatskaya, E., Fan, M., Li, X., Kuzyakov, Y. (2013): Microbial response to rhizodeposition depending on water regimes in paddy soils. - Soil Biology and Biochemistry 65: 195-203.

[38] Vance, E. D., Brookes, P. C., Jenkinson, D. S. (1987): An extraction method for measuring soil microbial biomass C. - Soil Biology and Biochemistry 19: 703-707.

[39] Wang, J. G., Lu, J. F. (1998): Analyses on the changes of soil fertility of North China Plain and the affecting factors. - Rural Eco-Environ 14: 12-16.

[40] Watanabe, T., Asakawa, S., Nakamura, A., Nagaoka, K., Kimura, M. (2004): DGGE method for analyzing 16S rDNA of methanogenic archaeal community in paddy field soil. - Fems Microbiology Letters 232: 153-163.

[41] Williams, A., Börjesson, G., Hedlund, K. (2013): The effects of 55 years of different inorganic fertiliser regimes on soil properties and microbial community composition. Soil Biology and Biochemistry 67: 41-46.

[42] Wu, H., Zeng, G., Liang, J., Zhang, J., Cai, Q., Huang, L., Li, X., Zhu, H., Hu, C., Shen, S. (2013): Changes of soil microbial biomass and bacterial community structure in Dongting Lake: Impacts of 50,000 dams of Yangtze River. - Ecological Engineering 57: 72-78.

[43] Wu, J., Joergensen, R. G., Pommerening, B., Chaussod, R., Brookes, P. C. (1990): Measurement of soil microbial biomass $\mathrm{C}$ by fumigation-extraction-an automated procedure. - Soil Biology and Biochemistry 22: 1167-1169. 
[44] Wu, M., Qin, H., Chen, Z., Wu, J., Wei, W. (2011): Effect of long-term fertilization on bacterial composition in rice paddy soil. - Biol Fert Soils 47: 397-405.

[45] Xu, Y., Wang, G., Jin, J., Liu, J., Zhang, Q., Liu, X. (2009): Bacterial communities in soybean rhizosphere in response to soil type, soybean genotype, and their growth stage. Soil Biology and Biochemistry 41: 919-925.

[46] Yuan, H., Ge, T., Zhou, P., Liu, S., Roberts, P., Zhu, H., Zou, Z., Tong, C., Wu, J. (2013): Soil microbial biomass and bacterial and fungal community structures responses to longterm fertilization in paddy soils. - Journal of Soils and Sediments 13: 877-886.

[47] Zhang, Y. F., Zhong, W. H., Li, Z. P., Cai, Z. C. (2006): Effects of long-term different fertilization on soil enzyme activity and microbial community functional diversity in paddy Soil derived from quaternary red clay. - J Ecol Rural Environ 22: 39-44.

[48] Zheng, S., Cao, H., Huang, Q., Liu, M., Lin, X., Li, Z. (2016): Long-term fertilization of $\mathrm{P}$ coupled with $\mathrm{N}$ greatly improved microbial activities in a paddy soil ecosystem derived from infertile land. - European Journal of Soil Biology 72: 14-20.

\section{APPENDIX}

Table A1. Sequences of $16 S$ rRNA gene fragments retrieved from DGGE bands

\begin{tabular}{|c|c|}
\hline $\begin{array}{l}\text { rDNA } \\
\text { gments }\end{array}$ & Sequences \\
\hline B1 & $\begin{array}{c}\text { CCTACGGGAGGCAGCAGTAAGGAATATTGGTCAATGGACGAAAGTCTGAACCAGCCATG } \\
\text { CCGCGTGGAGGATGAAGGTCCTCTGGATTGTAAACTTCTTTTATATGGGACGAAAAAAG } \\
\text { GCTTTTCCAAGTCGTCTGACGGTACCATATGAATAAGCACCGGCTAACTCCGTGCCAGCA } \\
\text { GCCGCGGTAAT }\end{array}$ \\
\hline B2 & $\begin{array}{l}\text { CCTACGGGAGGCAGCAGTGGGGAATATTGGACAATGGGCGCAAGCCTGATCCAGCAAC } \\
\text { GCCGCGTGGGGGATGAATGGCTTCGGCCCGTAAACCCCTGTCATTTGCGATCAAGGTGC } \\
\text { CGGGGTAAATAATCCCGGTACTTGACGGTACTGTCAGAGGAAGCCCCGGCTAACTCCGT } \\
\text { GCCAGCAGCCGCGGTAATA }\end{array}$ \\
\hline B3 & $\begin{array}{c}\text { CCTACGGGAGGCAGCAGTGGGGAATTTTGCGCAATGGGCGAAAGCCTGACGCAGCAAC } \\
\text { GCCGCGTGGAGGATGAAGGTCTTTGGATTGTAAACTCCTGTCAGCGGCGGAGAAGGGAC } \\
\text { TCGACCTCATAATCCCGGTACTTGACGGTACTGTCAGAGGAAGCCCCGGCTAACTCCGTG } \\
\text { CCAGCAGCCGCGGTAAT }\end{array}$ \\
\hline B4 & $\begin{array}{c}\text { ATTACCGCGGCTGCTGGCACGTAGTTAGCCGAGACTTATTCCTGGGATACTGTCCTTTCT } \\
\text { CATCTCCCAGAAAAGTGCTTTACGATCCGAAGACCTTCGTCGCACACGCGGCGTTGCTGG } \\
\text { GTCAGGCTTTCGCCCATTGCCCAATATTCCCTACTGCTGCCTCCCGTAGGA }\end{array}$ \\
\hline B5 & $\begin{array}{c}\text { ATTACCGCGGCTGCTGGCACGTAGTTAGCCGTGGCTTCCTCCAGAGGTATCGTCATTATC } \\
\text { GTCCCTCTAGACAAAGGTTTACGATCCGAAGACCTTCATCCCTCACGCGGCGTTGCTCGG } \\
\text { TCAGGCTTGCGCCCATTGCCGAAAATTCCCTACTGCTGCCTCCCGTAGGA } \\
\end{array}$ \\
\hline B6 & $\begin{array}{c}\text { ATTACCGCGGCTGCTGGCACGGAGTTAGCCGGTGCTTATTCCTCTGGTACCGTCAGTCCC } \\
\text { CATAGAGATAGGGGTTTCGTCCCAAAGAAAAGAAGTTTACAACCCAGAGGGCCTTCATC } \\
\text { CTCCACGCGGCATGGCTGGTTCAGACTTGCGTCCATTGACCAATATTCCTTACTGCTGCC } \\
\text { TCCCGTAGGA }\end{array}$ \\
\hline B7 & $\begin{array}{c}\text { CCTACGGGAGGCAGCAGTAGGGAATCTTCCGCAATGGACGAAAGTCTGACGGAGCAAC } \\
\text { GCCGCGTGAGCGATGAAGGCCTTCGGGTCGTAAAGCTCTGTTGTTAGGGAAGAACAAGT } \\
\text { ATCGGAGTAACTGCCGGTACCTTGACGGTACCTAACCAGAAAGCCACGGCTAACTACGT } \\
\text { GCCAGCAGCCGCGGTAATA }\end{array}$ \\
\hline B8 & $\begin{array}{c}\text { ATTACCGCGGCTGCTGGCACCTTTTTGCCCTATTACCGCGGCTGCTGGCACGTAGTTAGC } \\
\text { CGTGGCTTATTCCTCAGGTACTGTCCTTACTCCTCCCTGAGAAAAGAGGTTTACGACCCG } \\
\text { AAGGCCTTCTTCCCTCACGCGGCGTCGCTGTGTCAGGCTTTCGCCCATTGCACAATATTC } \\
\text { CTTGCTGCTGCCTCCCGTAGGA }\end{array}$ \\
\hline B9 & $\begin{array}{c}\text { CCTACGGGAGGCAGCAGTGGGGAATATTGGACAATGGGGGCAACCCTGATCCAGCCATG } \\
\text { CCGCGTGAGTGAAGAAGGCCTTCGGGTTGTAAAGCTCTTTCGGACGGAAAGAAATCGCC } \\
\text { ATTCCTAATACGAGTGGTGGATAACGGTACCGTCATAAGAAGCACCGGCTAACTACGTG } \\
\text { CCAGCAGCCGCGGTAATA }\end{array}$ \\
\hline
\end{tabular}




\begin{tabular}{|c|c|}
\hline B10 & $\begin{array}{l}\text { CAGACGTATTATCTTCCCGGTGAAAGAGCTTTACAACCCTAAGGCCTTCATCACTCACGC } \\
\text { GGCATGGCTGGATCAGGCTTGCGCCCATTGTCCAATATTCCCCACTGCTGCCTCCCGTAG } \\
\text { GGCCG }\end{array}$ \\
\hline B11 & $\begin{array}{c}\text { ATTACCGCGGCTGCTGGCACGGAGTTAGCCGGTGCTTCCTTCAGAGGTACCGTCAGGTCG } \\
\text { CCGACGTATTAGGTCGACGAGGTTTCGTCCCTCTTGACAGGGCTTTACGACCCGAAGGCC } \\
\text { TTCATCACCCACGCGGCGTCGCTGCGTCAGGCTTTCGCCCATTGCGCAAGATTCCCCACT } \\
\text { GCTGCCTCCCGTAGGA }\end{array}$ \\
\hline B12 & $\begin{array}{c}\text { ATTACCGCGGCTGCTGGCACGGAGTTAGCCGGGGCTTATTCTCCCGGTACTGTCATTATC } \\
\text { ATCCCGGGTAAAAGAGCTTTACAACCCTAAGGCCTTCATCACTCACGCGGCATTGCTGGA } \\
\text { TCAGGCTTTCGCCCATTGTCCAATATTCGCCACTGCTGCCTCCCGTAGGA }\end{array}$ \\
\hline B13 & $\begin{array}{c}\text { ATTACCGCGGCTGCTGGCACGTAGTTGGCCGGGGCTTCTTCTGCAGGTACCGTCAATTTC } \\
\text { GTCCCTGCTGAAAGCGGTTTACAACCCAAAGGCATTCATCCCGCACGCGGCGTTGCTGCG } \\
\text { TCAGGCTTTCGCCCATTGCGCAAGATTCCCCACTGCTGCCTCCCGTAGGA }\end{array}$ \\
\hline B14 & $\begin{array}{c}\text { CCTACGGGAGGCAGCAGTGAGGAATCTTGCGCAATGGGGGAAACCCTGACGCAGCAAC } \\
\text { GCCGCGTGAGTGAGGAAGGCTTTCGGGTCGTAAAGCTCTGTCAGATGGGAAGAAATGGA } \\
\text { TGGAAGCCAATACCTTTCATTCTTGACGGTACCATCAGAGGAAGCACCGGCTAACTCCGT } \\
\text { GCCAGCAGCCGCGGTAATA }\end{array}$ \\
\hline B15 & $\begin{array}{c}\text { CCTACGGGAGGCAGCAGTGGGGAATATTGCGCAATGGCCGAAAGGCTGACGCAGCGAC } \\
\text { GCCGCGTGTGGGATGAAGGTCTTCGGATCGTAAACCACTGTCGCGAGGGACGAAATTCT } \\
\text { GACGGTACCTCGAAAGGAAGCACCGGCTAACTCTGTGCCAGCAGCCGCGGTAATA }\end{array}$ \\
\hline B16 & $\begin{array}{c}\text { ATTACCGCGGCTGCTGGCACGGAGTTAGCCGGTGCTTCCTCTGATGGTACCGTCAGACAC } \\
\text { AGGGACTGTTTATCCCTATGCGGTTCTTTCCATCTGACAGAGCTTTACGATCCGAAGACC } \\
\text { TTCCTCACTCACGCGGCGTTGCTGCGTCAGGGTTTCCCCCATTGCGCAAGATTCCTCACT } \\
\text { GCTGCCTCCCGAGGA }\end{array}$ \\
\hline B17 & $\begin{array}{c}\text { ATTACCGCGGCTGCTGGCACGAAGTTAGCCGGGGCTTCTTCTGCGGGTACCGTCATTATC } \\
\text { GTCCCCGCTGAAAGAATTTTACAATCCTAAGACCTTCATCATTCACGCGGCATGGCTGCG } \\
\text { TCAGGCTTTCGCCCATTGCGCAAGATTCCCTACTGCTGCCTCCCGTAGGA }\end{array}$ \\
\hline B18 & $\begin{array}{c}\text { ATTACCGCGGCTGCTGGCACGTAGTTGGCCGGTGCTTCTTCTGTAGGTACCGTCACGTTA } \\
\text { GCTTCGTCCCTACTGAAAGAGGTTTACAACCCGAAGGCCGTCATCCCTCACGCGGCGTTG } \\
\text { CTGGATCAGGCTTTCGCCCATTGTCCAATATTCCCCACTGCTGCCTCCCGTAGGA }\end{array}$ \\
\hline B19 & $\begin{array}{c}\text { ATTACCGCGGCTGCTGGCACAGAGTTAGCCGGGGCTTCCTCTGCGGGTACAATCAAGTCC } \\
\text { CCGACGTATGAGGTCGAGTCCCTTTTTCCCCGCTGACAGGAGTTTACAATCCAAAGACCT } \\
\text { TCATCCTCCACGCGGCGTTGCTGCGTCAGGCTTTCGCCCATTGCGCAAAATTCCCCACTG } \\
\text { CTGCCTCCCGTAGG }\end{array}$ \\
\hline B20 & $\begin{array}{c}\text { ATTACCGCGGCTGCTGGCACGAAATTATGCGGTGCTTATTCCTCACGTACCGTCAGCCCC } \\
\text { ACCGGGTATTATCCGGGACTATTTCTCTCCTGAGAAAATAGGTATACAACCCGAAGGCCT } \\
\text { CCATCCCTCACGCGGCGTTGCTGCTTCTAGCTTTCGCCCATTGAGCAAAATTCCCGACTG } \\
\text { CTGCCTCCCGTAGGA }\end{array}$ \\
\hline B21 & $\begin{array}{c}\text { CCTACGGGAGGCAGCAGTGGGGAATATTGGACAATGGGCGCAAGCCTGATCCAGCAAC } \\
\text { GCCGCGTGGAGGACGAAGGTCTTCGGATCGTAAACTCCTGTCAGACGGGACGAAGGTGC } \\
\text { CTGGGTAAATAATCCAGGTGCTTGACGGTACTGTCAGAGGAAGCCCCGGCTAACTCCGT } \\
\text { GCCAGCAGCCGCGGTAATA }\end{array}$ \\
\hline B22 & $\begin{array}{l}\text { CCTACGGGAGGCAGCACTGAGGAATATTGGTCAATGGGCGGAAGCCTGAACCAGCCATC } \\
\text { CCGCGTGCATGAAGACTGCCCTATGGGTTGTAAACCGCTTTTCCAGGGGGTGAATAGTCG } \\
\text { CGACGTGTCGTGGCATGACGGTACCCTGGGAATAATCATCGGCTAACTCCGTGCCAACA } \\
\text { GCCGCGGTAATAGGGCAAAAAGGTGGACATTGGGATCCTACCAGCATCCAGCAGCCGCG } \\
\text { GTAATT }\end{array}$ \\
\hline B23 & $\begin{array}{c}\text { ATTACCGCGGCTGCTGGCACGTAGTTAGCCGGTGCTTCTTCTTACGGTACCGTCATCCCC } \\
\text { ACCCGGTATTAGCGGATAGGATTTCTTTCCGTCCGAAAGAGCTTTACAACCCCAAAGACT } \\
\text { TCTTCACTCACGCGGCATGGCTGGATC }\end{array}$ \\
\hline B24 & $\begin{array}{l}\text { CCTACGGGAGGCAGCAGTGGGGAATATTGGACAATGGGCGGAAGCCTGATCCAGCAAC } \\
\text { GCCGCGTGAGGGATGACGGCCTTCGGGTTGTAAACCTCTTTCAGTAGGGACGAAGCGCA } \\
\text { AGTGACGGTACCTACAGAAGAAGCACCGGCCAACTACGTGCCAGCAGCCGCGGTAATA }\end{array}$ \\
\hline B25 & $\begin{array}{l}\text { TACCGCGGCTGCTGGCACGTAGTTAGCCGTGACTTATTCATCAGGTACCGTCATTATTCTT } \\
\text { CCCTGATAAAAGAGGTTTACGACCCGAAGGCTGTCCTCCCTCACGCGGTGTTGCTGCGTC } \\
\text { AGGCTTTCGCCCATTGCGCAAAATTCCCTGCTGCTGCCTCCCGTAA }\end{array}$ \\
\hline
\end{tabular}

